\title{
The relationship between corporate governance characteristics and agency costs*
}

\author{
Mahdi Salehi ${ }^{1}$, Mohammad Sadegh Adibian ${ }^{2}$, Zakiyeh Sadatifar ${ }^{3}$, \\ Ehsan Khansalar ${ }^{4}$
}

\begin{abstract}
The present study aims to evaluate the contributing factors to agency costs in Iran. In this regard, 112 companies were studied over 2010 - 2016. Since the model is dynamic and the dependent variable suffers from a lag, the generalized method of moments is employed to free the independent variables and the disruptive component. The findings indicate a significant lag in the dependent variable of all three models. An audit committee's presence significantly affects the decline of agency costs in all three models. Moreover, results suggest that family companies and the state shareholders of all three models have no significant impact on the agency costs. The existence of financial leverage matching with all three models causes the decline of agency costs. In terms of assets, Larger companies based on the three models have more agency costs as well.
\end{abstract}

Key words: agency costs, dynamic panel, generalized method of moments, factor analysis, and audit committee

JEL classification: M41, C18

\footnotetext{
Received: 20-03-2020; accepted: 27-06-2021

1 Associate Professor of Accounting, Ferdowsi University of Mashhad, Postal code 9177948974 , Mashhad, Iran. Scientific affiliation: auditing and financial reporting. Phone:+989121425323. E-mail: mehdi.salehi@um.ac.ir. (Corresponding author)

2 PhD student, Ferdowsi University of Mashhad, Mashhad, Postal code 9177948974, Iran. Scientific affiliation: econometric methods and models, corporate finance. Phone: 989157001093.E-mail: Adib.mohammad@gmail.com.

${ }^{3}$ M.A. in Accounting Imamreza International University of Mashhad, Postal code 916789412, Mashhad, Iran. Scientific affiliation: auditing and accounting.E-mail: saadate94@gmail.com.

4 Associate Professor of Accounting, Kingston University London, London, the UK. Scientific affiliation: financial reporting and accounting.Phone: +44752 8593389.E-mail: e.khansalar@ kingston.ac.uk.
} 


\section{Introduction}

Any firm's goal is to try to have the desired performance to increase the value of the firm's shares, achieve greater profits, and ultimately increase shareholders' interests and satisfaction. Therefore, to achieve these goals, each firm must identify the factors that moderate the above goals' achievement. Agency costs are one of the factors whose increase has a negative impact on the shareholders' interests. Because increasing agency costs reduce the firm shareholders' value, ask the managers to manage the firm to increase the firm value (Dawar, 2014). The people of society seek to increase their interests, and managers are no exception to the case and want to, along with maximizing their interests, social welfare, and stabilizing their job position, provide a sound image of the financial status of the business firm to shareholders. The problem here is that, in some cases, the increase of the managers' wealth, as a result of decreasing shareholder benefits (Kim et al., 2012). This reflects a lack of conformity among managers' interests and other beneficiary groups within a business firm (Salehi et al., 2020).

To assume that both the manager and the owner think about maximizing their own interests emphasizes that an agent does not always work to the client's benefit. In other words, one of the agency problems is the presence of a conflict of interests between owner and manager. Numerous studies on the conflict of interests between managers and owners, especially after recent financial scandals in large global companies (Kilic, 2015), declared that the potential conflict of interests between managers and scattered shareholders provokes when managers have no ownership rights. Therefore, the firm's control is likely to be to managers' service rather than to implement shareholders' interests by the management's higher expertise.

One of the other agency problems is the incapability of the shareholder to monitor the manager's operations. A shareholder cannot pursue the managers' daily actions to be ensured whether or not the decisions are made following the interests of the shareholders (Salehi et al., 2020). Thus, the shareholder is deprived of the required information, which is called information asymmetry. In the agency theory, such additional information of the manager is called private information. The presence of private information gives rise to information asymmetry between the shareholder and manager. Therefore, the shareholders incur the agency costs for downsizing the crippling effects of the conflict of interests (Manos et al., 2012).

The agency costs are made of both parties' conflicts of interests by the agency relation's emergence. Broadly, we could say that the agency costs are those expenses derived from the conflict of interests between shareholders, bondholders, and business managers. Such a conflict of interest is often due to two main reasons, first, the difference in objectives and beliefs of shareholders, and second, the difference and the information asymmetry of participants about the firm and its performance (Buchwald, 2016). Hence, by bearing some costs, called the agency 
costs, shareholders would be able to curtail the damaging effect of separation of ownership and management.

Since managers eventually incur the monitoring costs, they are willing to trust owners not to do action hurting their profit. The manager's consumed resources to earn the trust of owners are called the commitment costs. For instance, the owners' costs for disclosing additional information may lower the supervision and benefit the managers. Commonly, managers are willing to bear such costs until the final costs of commitment are equal to the decline of the monitoring costs.

In most agency relations, owners and managers carry the costs of monitoring and commitment. However, likely, the CEO's decisions do not conform to the maximizing decisions of owners' profit; in Rial currency, such a downturn in owners' welfare due to such conformity is called the residual loss (Jensen, 1986). Hence, when both parties to the agency relationship are expected to behave logically to maximize their interests, such a relation could be problematic because it is impossible to do so.

To lessen the agency costs, shareholders require a mechanism for controlling and decreasing the costs, one of which is the corporate governance mechanism. Improving firm performance due to favorable corporate governance would increase the firm's stock value and provide an opportunity for capital attraction (Yeo, 2012). Therefore, by upgrading the governance, the desired capital will be attracted by the investors from the local markets, but the foreign investors will be assured of investing in such companies (Salehi and Salimi, 2017). Good corporate governance by enhancing the firm performance and information transparency reduces the conflict of interests between shareholders and owners, decreases the information asymmetry between the shareholder and manager, satisfies the shareholders, and lowers agency costs (Hong et al., 2015). Thus, the corporate governance system's mechanisms have various aspects that reduce the agency conflict and may differ between alternative and complementary sides. Therefore, the present study examines whether corporate governance characteristics, including the audit committee, CEO tenure, family ownership, and state ownership, affect agency costs? And if so, how does each affect agency cost, positive or negative?

Therefore, the following hypotheses are postulated in the study:

$\mathrm{H}_{1}$ : There is a significant relationship between the audit committee and the agency costs.

$\mathrm{H}_{2}$ : There is a significant relationship between CEO tenure and agency costs.

$\mathrm{H}_{3}$ : There is a significant relationship between family ownership and agency costs.

$\mathrm{H}_{4}$ : There is a significant relationship between state ownership and agency costs. 
The research >s brief structure is as follows: The second part of the research is related to reviewing the literature related to financial leverage, company size, audit committee, CEO tenure, Family ownership, and State ownership. The third part is related to research methodology, including introducing the statistical population, research models, variables, and how to measure them. The fourth part is related to estimating models and analyzing the obtained information. Finally, the last part is related to the discussion and the results of the research.

\section{Literature review}

\subsection{Audit committee}

In general, Jensen defined agency costs as follows: Monitoring costs of a manager by the owner:

These costs comprise the owners' efforts for evaluating, observing, and controlling the agent's behavior. Such an attempt may include the independent auditor's payment, compensation plans, and/or limitations on budget, etc. The owners incur these costs, but Fama and Jensen (1983) argue that they could finally modify a manager's rewards and benefits. Another alternative to monitoring managers is the audit committee. The audit committee's supervision is one strategy to enhance information flow between shareholders and managers (Rouf, 2011). The audit committee is a component of internal control, improving rate governance, and fewer leniency costs (Klein, 2002; Ilaboya and Obaretin, 2015). An internal control system is a management tool helping the profitability and enhancement of the firm performance and hindering the waste of firm resources (Hunzikera, 2014). When the agency costs soar, it demands highquality audit increases, as well. This occurs either voluntarily as a medium mechanism or externally as a control mechanism by shareholders and creditors. Auditors gain more data collection and more accurate judgment with auditors' specialization and professional advancement. Therefore, we could state that the demand for specialized auditors is grown. To have more careful information flow supervision, the audit committee should grasp managerial and financial accounting's required expertise. The specializations needed for monitoring would reduce internal control, lowering agency costs (Yang and Krishnan, 2005). Dey (2005) concluded that in companies with the highest agency costs, the audit committee's effectiveness has a positive and significant relationship with the quality of benefit.

Beshkooh et al. (2015) showed a negative and significant relationship between agency costs and audit quality.

Therefore, the audit committee as an internal control can affect the agency costs by improving the transparency of financial statement information, so the audit committee s effectiveness on agency costs is likely negative and significant. 


\subsection{CEO tenure}

To increase the firm value and enhance profitability, most shareholders tend to use highly qualified managers. Hence, the increase of knowledge and experience could cause lower CEO tenure on the board. However, a longer tenure may establish a friendship between the board members and the CEO, downplaying the management's supervision role. Short-time CEO tenure causes the investments to be of higher priority than quicker returns, and investments that create long-term values would be avoided (Antia et al., 2010). Some scholars believe that as the CEO tenure increases, the sense of responsibility for controlling the decisions taken grows, plans will be more purposeful, and the firm characteristics and the opportunities and threats become clearer. These factors would develop more sensitivity concerning the decisions taken and the control of plans.

Consequently, longer management tenure is a long-term commitment to improving firm performance and decreasing agency costs (Arosa et al., 2013). Anita et al. (2010) indicate that the CEO's short-term decision-making horizon causes the investments to be the top priority with the fastest returns possible. Those that create long-term values will be ignored. Zhang (2010) concluded that compensation based on the percentage of equity increases the firm performance at the beginning of their tenure for the managers. For the internal managers, this variable decreases at the end of their tenure.

\subsection{Family ownership}

The ownership structure is different for various companies. It is a type of ownership in which real shareholders are the members of a family or are relatives and, by holding a high percentage of stocks or affiliation in the board, greatly influence the firm (Anderson et al., 2003).

According to the agency theory, the conflict of interests could obsess the owners (shareholders) to the point that they evaluate the managers to be ensured that optimal resources are allocated to the managers. We realized that some managerial decisions could waste the firm resources and destruct owners' wealth. On the other hand, managers have always sought to maximize their interests and ensure that their decisions benefit them. Based on an approach, due to the creation of good fame, in the long run, family ownership is encouraged, and activities like earnings management, which have short-term effects, should be avoided (Wang, 2006). Several studies put forward to test the management problems and different types of control derived from such an organizational structure (Gonzales et al., 2010).

The most important issue in the studies on family ownership is how to define such firms. Generally, family ownership refers to those firms, the shares of which are at the possession of a family, and the family members are the board members at 
the same time or are working on different managerial and operational positions. Due to lower agency costs, those firms operate by family foundations and should be more efficient than the state institutions. The available evidence in the agency costs literature suggests that any increase in family shareholders' ownership and management causes fewer agency conflicts (Alton et al., 2007). Anderson et al. (2003) noticed that family ownership incurs fewer financial supply costs.

This is in line with the idea that family ownership has some goals to reduce agency costs between owners and firm creditors. Chrisman et al. (2004) showed that the agency problem in family ownership is less than that of the non-family firms. Fleming et al. (2005) showed an increase in family ownership could lower agency costs. Chrisman et al. (2007) show that family managers are under the supervision of and support family owners using a driver named compensation. Given the family managers' higher performance, we could guess such firms' agency behavior and confirm firm performance enhancement theory by establishing agency costs control mechanisms.

\subsection{State ownership}

The ownership structure has a pivotal and specified position in the corporate governance system. Determining the type of ownership structure and the shareholders' composition is a control and governance tool in firms. After leadership, the issue also contributes to different determining factors of ownership type, including ownership distribution, ownership concentration, the presence of minority shareholders in ownership composition, and ownership percentage. Moreover, firms' stock composition follows a different pattern like institutional ownership, managerial ownership, and private and state shareholders (Li et al., 2007).

In some studies, the state is considered a major investor, and in some others, state ownership is more than just a shareholder. The state-owned companies are those establishments; more than $5 \%$ of their shares belong to the state, state, or state firms, including insurance, financial institutions, banks, state companies, and other state sectors (Firth et al., 2008).

Several studies demonstrate that state ownership imposes some costs on the state and, consequently, brings about less profitability and lower firms' stock value. On the other hand, some scholars showed that state-owned companies, due to their access to financial resources, enjoy higher profitability. Their stock value will grow in the capital market.

Salehi et al. (2020) indicate that the greater number of board directors' meetings improves agency costs. They also highlighted that the higher educational level of board members decreases the agency cost. Further, they illustrated that women's presence in the board of directors, the ownership of firms' board of directors, 
board members' bonuses, and independence decrease agency costs. Further, they documented that $\mathrm{CEO}$ duality plays a significant role in worsening agency costs in the statistical population.

Firth et al. (2008) found that institutional ownership and state ownership have no significant effect on agency costs.

\subsection{Financial leverage}

Financial leverage is a factor that captured other stakeholders' attention, like creditors, and consequently directs them to stricter supervision. This variable indicates the extent to which the firm could rely on long-term debts and borrowings to supply its required financial supply. Counting on debt as a governance characteristic is based on the view that creditors analyze the management performance. Some believe that the increase in debt inflates bankruptcy risk (Oberdavich and Gill 2013). Li and Gui (2003) argued that debts lower agency costs. Byrd (2010) declared a conflict of interest between managers and shareholders on spending free cash flows. The results of this study indicate that there is an inverse relationship between financial leverage and agency costs. Moussa and Chichti (2011) showed that the debt policy is a major mechanism for controlling the agency problems of free cash flows. Nazir and Satia (2013) found a negative relationship between these two variables. Brewer and Featherstone (2017) noticed a significant relationship between financial leverage and agency costs. Russell et al. (2017) found a negative and significant relationship between these two variables.

\subsection{Firm size}

Due to less complication, decision-making and control seem easier in small firms, and monitoring in such firms, compared with large companies, will be decreased (Arosa et al., 2013). Due to various operations, large companies are less on the brink of bankruptcy, enjoy a more comprehensive organizational structure, and incur more agency costs (Garanina and Kaikova, 2016). The firm size indicates its competitive advantage, and since a higher share of the market asks for more production and sales, having ample and larger financial resources help the firm produce more and spend freely on production and marketing to generate competitive advantages. Firm size also reflects the managerial ability and the quality of accounting plans. The development of firm size signals powerful management that tries to increase the economic resources using the accounting plans. Current studies demonstrate that there is a positive relationship between firm size and agency costs. Zhang and $\mathrm{Li}$ (2008) assessed the relationship between agency costs and the financial leverage of companies and found a positive and significant relationship between these two variables. 


\section{Methodology}

The information software of Tadbir Pardaz and Rah Avar-e Novin was used to gather information from the audited financial statements of listed companies on the Stock Exchange.

The statistical population comprises all companies listed on the Tehran Stock Exchange. In this study, the screening method was used for selecting the samples, such that first all companies were selected during 2010-2016, then companies with the following qualifications were included:

- Being accepted to the Securities and Exchange before 2010;

- The financial yearend should be on March 20;

- Should not change their fiscal year;

- Should not be affiliated with non-financial companies, like banks, investment, and holding companies, because the nature of such companies is different; and

- Their financial information should be available.

Given the above-said limitations, finally, a total of 112 listed companies on the Tehran Stock Exchange were selected. Excel's spreadsheet software was used to summarize the information, and the hypotheses were tested using the Eviews 10 Software.

\subsection{Research models and variables}

Since the dependent variable of the research has been measured in 3 different ways, so the present study has 3 models as follow:

Model 1)

$$
\begin{aligned}
& A \operatorname{COST1}_{i t}=\beta_{0}+\beta_{1} A \operatorname{ACOST1}(-1)_{i t}+\beta_{2} D E B T_{i t}+\beta_{3} A C S_{i t}+\beta_{4} \operatorname{STATE}_{i t}+ \\
& \beta_{5} \operatorname{TENUE}_{i t}+\beta_{6}\left(F_{A M I L Y}-\text { FIRM }_{i t}\right)+\beta_{7}\left(F I R M-A G E_{i t}\right)+\beta_{8} \operatorname{SIZE}_{i t}+e_{i t}
\end{aligned}
$$

Model 2)

$$
\begin{aligned}
& A \operatorname{COST2}_{i t}=\beta_{0}+\beta_{1} A C O S T 2(-1)_{i t}+\beta_{2} D E B T_{i t}+\beta_{3} A C S_{i t}+\beta_{4} \operatorname{STATE}_{i t}+ \\
& \beta_{5} \operatorname{TENUE}_{i t}+\beta_{6}\left(F_{A M I L Y}-\text { FIRM }_{i t}\right)+\beta_{7}\left(F I R M-A G E_{i t}\right)+\beta_{8} \operatorname{SIZE}_{i t}+e_{i t}
\end{aligned}
$$

Model 3)

$$
\begin{aligned}
& A_{C O S T 3}{ }_{i t}=\beta_{0}+\beta_{1} A C O S T 3(-1)_{i t}+\beta_{2} D E B T_{i t}+\beta_{3} A C S_{i t}+\beta_{4} \operatorname{STATE}_{i t}+ \\
& \beta_{5} \operatorname{TENUE}_{i t}+\beta_{6}\left(F_{A M I L Y}-\text { FIRM }_{i t}\right)+\beta_{7}\left(F I R M-A G E_{i t}\right)+\beta_{8} \operatorname{SIZE}_{i t}+e_{i t}
\end{aligned}
$$




\subsubsection{Dependent variable:}

3.1.1.1. ACOST1: The inverse asset turnover ratio is achieved from the inverse annual sales division on total assets and indicates the agency costs. The asset turnover ratio in the studies of Ang et al. (2000) and Sing and Davidson (2003) is also used as a variable with an inverse relationship with the agency costs. Here, we use the inverse value, which is directly associated with agency costs.

3.1.1.2. ACOST2: Are operation costs to sales ratio. An operational cost encompasses the marketing costs, sales advertisements, and rent costs and somehow reflects the managerial authorities in consuming the firm resources. This index is used as the direct criterion for agency costs. The higher the index, the higher the agency costs would be. So, an operational cost to sales ratio is indicative of the managerial authorities for consuming the firm resources (Florakis, 2008).

The accurate measurement of agency costs is one of the most complicated issues. Two variables of inverse asset turnover ratio and operational costs to sales ratio demonstrate the relative amount of the agency costs and assign a ratio to the agency costs from different aspects. In this paper, factor analysis is used to include these two variables. The SPSS25 Software, KMO test statistic, and Bartlett test were used to measure the factor analysis's appropriateness. The value of the KMO test statistic is 0.54 . So, we can cautiously say that data are suitable for the factor analysis. Further, we test the null hypothesis, based on the Bartlett test, to determine whether or not the correlation matrix among the variables is related to a population with uncorrelated variables. The calculated probability level is 0.01 , so the null hypothesis is rejected, and the data are suitable for the factor analysis.

3.1.1.3. ACOST3: two variables of inverse asset turnover ratio and operational costs to sales ratio achieved from the factor analysis, indicating the agency costs index.

\subsubsection{Independent variables:}

Agency cost lag $(\operatorname{ACOST}(-1)$ : to protect shareholder interests and lessen the conflict of interests, shareholders are willing to pay the agency costs. Given that, we could declare that the increase of operational costs to sales within a year is indicative of the decrease of the firm performance and, consequently, the decline of shareholders' interests. This could encourage the shareholders to incur more agency costs to prevent a higher decline in their firm's interests. Hence, we could say that a part of the agency costs has some endogenous reasons, signifying that the previous periods' agency costs could affect the present. Independent of changes in other exogenous variables, a firm with high agency costs in the t period would experience relatively higher agency costs in the upcoming period. Those structures 
that shape during the working groups are often more willing to survive and double their attempts to preserve the previous conditions.

Financial leverage (DEBT): to measure the variable, firm debt is divided by the firm assets.

Audit committee (ACS): this variable is considered a dummy, such that if the firm has an audit committee, it takes 1 ; otherwise, 0 .

Firm size (SIZE): in this paper, according to Dawar's (2014) study, we tried to assess the impact of firm size. Hence, to measure the firm size, the natural logarithm of firm assets is used.

State ownership (STATE): the criteria for measuring this variable is the index values. If the state is the shareholder, it takes 1 ; otherwise, 0 .

CEO tenure (TENUE): to measure the variable, if the CEO tenure is more than 3 years, it takes 1 ; otherwise, 0 .

Family companies (FAMILY-FIRM): this variable is an index, such that if the firm operates by a family, it takes 1 ; otherwise, 0 will be assigned.

Firm age (FIRM-AGE): the number of years passed from the firm establishment is considered.

\section{Empirical data and analysis}

\subsection{Research findings}

\subsubsection{Descriptive statistics}

The descriptive statistics of research variables are calculated for the initial data analysis and presented in Table 1. As depicted in Table 1, given the relative closeness of the mean and median in most variables, we could declare that all variables have an appropriate statistical distribution. Their standard deviation is not 0 , so we can enter the desired variables into the model. 
Mahdi Salehi et al. - The relationship between corporate governance characteristics...

Table 1: Descriptive statistics

\begin{tabular}{|l|r|r|r|r|r|r|r|}
\hline \multicolumn{1}{|c|}{ Variables } & Mean & Median & Maximum & Minimum & $\begin{array}{r}\text { Standard } \\
\text { deviation }\end{array}$ & Skewness & Kurtosis \\
\hline ACOST1 & 1.490 & 1.270 & 7.280 & 0.150 & 0.880 & 1.790 & 8.530 \\
\hline ACOST2 & 0.310 & 0.120 & 38.310 & 0.000 & 2.000 & 15.560 & 262.390 \\
\hline ACOST3 & 1.160 & 0.960 & 22.290 & 0.060 & 1.150 & 10.570 & 170.540 \\
\hline DEBT & 0.670 & 0.640 & 3.060 & 0.060 & 0.330 & 2.440 & 14.810 \\
\hline FIRM_AGE & 36.840 & 40 & 64 & 6 & 14.30 & -0.220 & 1.800 \\
\hline SIZE & 13.730 & 13.40 & 18.900 & 10.100 & 1.670 & 0.760 & 3.400 \\
\hline
\end{tabular}

Source: Research Database

Table 1-2: Descriptive statistics (dummy variable)

\begin{tabular}{|l|r|r|r|r|r|r|r|}
\hline \multicolumn{1}{|c|}{ Variables } & Mean & Median & Maximum & Minimum & $\begin{array}{r}\text { Standard } \\
\text { deviation }\end{array}$ & Skewness & Kurtosis \\
\hline ACS & 0.530 & 1 & 1 & 0 & 0.490 & -0.130 & 1.010 \\
\hline FAMILY_FIRM & 0.080 & 0 & 1 & 0 & 0.270 & 2.970 & 9.860 \\
\hline STATE & 0.800 & 1 & 1 & 0 & 0.390 & -1.570 & 3.400 \\
\hline TENUE & 0.490 & 0 & 1 & 0 & 0.500 & 0.030 & 1.000 \\
\hline
\end{tabular}

Source: Research Database

Low standard deviation indicates low data scatter from the mean, and high standard deviation indicates high data scatter from the mean. In the table for non-dummy variables, as it is known, the age variable of the company with a standard deviation of 14.3 has the highest dispersion of the average, which is due to the definition of the variable and given that this variable always changes for each year. It is correct and logical. And the debt variable with a standard deviation of 0.33 has the lowest scatter of the average, which means that usually, the debt-to-assets ratio of companies does not change much over time. In the study of skewness coefficient, it is observed that all the studied variables have a positive skewness coefficient, i.e., higher than the normal distribution.

In the descriptive statistics table for dummy variables, as it is known, the TENUE variable with a standard deviation of 0.5 has the highest dispersion of the average. The FAMILY-FIRM variable with a standard deviation of 0.27 has the lowest dispersion of the average, meaning that companies run as a family, mostly running the same way and not changing throughout the year. 


\subsubsection{Pattern estimation}

One of the drawbacks of the agency cost in the conducted studies is ignoring the agency's endogeneity issues. The present study, due to the presence of a lagged dependent variable in the right side of the equation and pattern estimation, is biased and incompatible, so use two-step estimation methods of 2SLS or Generalized Method of Moments (GMM) is necessary. 2SLS estimation model may, due to a problem in tools selection, provide large variances for the coefficients and, while the variables could affect the dependent variable, make the estimation statistically insignificant. Hence, the GMM method proposed by Arellano and Bond (1991) for this purpose is one of the major assumptions: the relationship between independent variables and the disruptive component (residuals) is not classic. When the method enters the lagged dependent variable method as an independent variable and the number of cross-sections is more than the number of periods, a relationship and correlation is established between the dependent variable (lagged dependent variable) and the disruptive component (residuals). Within the GMM method, instrumental methods are used to deal with the problem. The compatibility of the GMM's estimators depends on the variability of the applied instruments. Within the Sargan test, the null hypothesis is about the lack of correlation between instrumental variables and the disruptive component (instrument reliability). In contrast, the alternative assumption tests the correlation of instrumental variables and the disruptive component (invalidity of instruments and, consequently, the estimation). Within the test of serial correlation of regression model residuals, the disruptive sentences should have a first-order serial correlation AR (1), not the second-order serial correlation AR (2).

Table 2 depicts the results of the first model fitting.

Table 2: The results of the first model fitting

\begin{tabular}{|l|r|r|r|r|}
\hline \multicolumn{1}{|c|}{ Model (ACOST1 is the dependent variable) } & \multirow{2}{*}{ Coefficient } & \multicolumn{1}{c|}{$\begin{array}{c}\text { standard } \\
\text { error }\end{array}$} & statistics & \multirow{2}{*}{ prob } \\
\cline { 1 - 2 } Interrupt variable interrupt & 0.070 & 0.026 & 2.870 & $* * * 0.000$ \\
\hline ACS & -0.100 & 0.022 & -4.630 & $* * * 0.000$ \\
\hline DEBT & -0.910 & 0.0315 & -2.890 & $* * * 0.000$ \\
\hline FAMILY_FIRM & 1.060 & 0.990 & 1.070 & 0.280 \\
\hline FIRM_AGE & -0.010 & 0.007 & -1.880 & $* 0.060$ \\
\hline SIZE & 0.300 & 0.030 & 8.330 & $* * * 0.000$ \\
\hline STATE & -0.140 & 0.150 & -0.940 & $* * 0.034$ \\
\hline TENUE & 0.060 & 0.010 & 5.250 & $* * * 0.000$ \\
\hline
\end{tabular}

Notes: ***Significance level is $99 \%$ confidence, $* *$ Significance level is $95 \%$ confidence and * Significance level is $90 \%$ confidence.

Source: Research findings 
Based on the results, the lagged dependent variable's effect is positive and significant on the agency costs, which signals if the agency costs increase during the current period and increase and control in the next period. We still have time for the full adjustment of the agency costs, and such costs will be increased in the second run due to the escalation of the previous period. The audit committee's impact on the agency costs, as expected, is negative and significant and indicates that the presence of such a committee could curtail the agency costs.

The effect of financial leverage on agency costs, based on this model, is negative and significant.

In this paper, we assumed that firms operating by a family enjoy lower agency costs, and the increase of ownership and family shareholder management declines the agency conflicts. Still, the results show that family companies were also not able to prevent agency costs.

The impact of state ownership on the agency costs was not significant, which contrasts with the study's expectation.

Thus, results indicate that though management could lead to more experience, it caused higher agency costs and the rejection of managers' longer tenure efficiency in terms of agency costs.

The effect of firm age on agency costs is negative and significant, so companies with longer ages and establishment have lower agency costs.

In this model, dependent variable lags were used as the instrumental variables. The estimator validity of the GMM method depends on the validity of the instrumental variables. In this paper, the Sargan and serial correlation of model residuals tests were employed to assess the validity of the instrumental variables.

The results of the Sargan test showed that the statistic of this test is equal to 7.64, and its probability level is 0.36 . So the test's null hypothesis is not rejected based on the statistic and probability level's value because the instrumental variables and the disruptive component are not correlated and have no validity.

The results of the serial correlation test of model residuals are presented in the following table.

Table 3: serial correlation test of the first model residuals

\begin{tabular}{|l|c|c|}
\hline \multicolumn{1}{|c|}{ Autocorrelation order } & Statistic & Probability level \\
\hline First & 24.700 & 0.000 \\
\hline Second & 0.540 & 0.460 \\
\hline
\end{tabular}

Source: Research findings 
The following table presents the results of the estimation of the second model.

Table 4: the results of the second model fitting (dependent variable of ACOST2)

\begin{tabular}{|l|r|r|r|r|}
\hline \multicolumn{1}{|c|}{ Model } & Coefficient & $\begin{array}{c}\text { Standard } \\
\text { deviation }\end{array}$ & \multicolumn{1}{c|}{ T statistic } & Probability level \\
\hline Lagged dependent variable & 0.08 & 0.05 & 14.28 & 0.00 \\
\hline ACS & -0.125 & 0.020 & -5.070 & $* * * 0.000$ \\
\hline DEBT & -0.480 & 0.070 & -6.640 & $* * * 0.000$ \\
\hline FAMILY_FIRM & 0.050 & 0.040 & 1.240 & $* * * 0.000$ \\
\hline FIRM_AGE & -0.030 & 0.010 & -2.770 & $* * * 0.000$ \\
\hline SIZE & 0.210 & 0.050 & 3.550 & $* * * 0.000$ \\
\hline STATE & -0.070 & 0.060 & -1.200 & 0.225 \\
\hline TENUE & 0.050 & 0.020 & -2.480 & $* * 0.015$ \\
\hline
\end{tabular}

Notes: ***Significance level is $99 \%$ confidence, $* *$ Significance level is $95 \%$ confidence and * Significance level is $90 \%$ confidence

Source: Research findings

According to the obtained results, the lagged dependent variable has a positive and significant effect. In the second model, where the dependent variable is the operational costs to sales ratio, the lagged dependent variable coefficient has the most value. This signals that the factors contributing to the agency costs are the agency costs value of the prior period. In other words, high operational costs to sales ratio in the $t$ period cause the increase of this ratio in the upcoming period, even if their actuators exist no longer. The effectiveness of the audit committee on the operational costs is negative and significant.

The firm age effect on the operational costs is negative and significant. The relationship between firm size and agency costs is positive and significant. There is no such relationship between state ownership and agency costs, and the effectiveness of CEO tenure on the agency costs is positive and significant. The obtained results, in terms of significance and coefficient sign, are like model 1.

The results of the Sargan test showed that the statistic of this test is equal to 4.89, and its probability level is 0.670 . So the test's null hypothesis is not rejected based on the statistic and probability level's value because the instrumental variables and the disruptive component are not correlated and have no validity. 
Mahdi Salehi et al. - The relationship between corporate governance characteristics...

The results of the serial correlation test of model residuals are presented in the following table.

Table 5: Serial correlation test of the second model residuals

\begin{tabular}{|l|c|c|}
\hline \multicolumn{1}{|c|}{ Autocorrelation order } & Statistic & Probability level \\
\hline First & 118.040 & 0.000 \\
\hline Second & 0.020 & 0.880 \\
\hline
\end{tabular}

Source: Research findings

The following table presents the results of the estimation of the third model.

Table 6: The results of the third model fitting (dependent variable of ACOST3)

\begin{tabular}{|l|r|r|r|r|}
\hline \multicolumn{1}{|c|}{ Model } & Coefficient & $\begin{array}{r}\text { Standard } \\
\text { deviation }\end{array}$ & T statistic & $\begin{array}{r}\text { Probability } \\
\text { level }\end{array}$ \\
\hline Lagged dependent variable & 0.230 & 0.080 & 2.690 & 0.000 \\
\hline ACS & -0.080 & 0.030 & -2.530 & 0.010 \\
\hline DEBT & -0.340 & 0.190 & -1.760 & 0.070 \\
\hline FAMILY_FIRM & 0.080 & 0.140 & 0.610 & 0.545 \\
\hline FIRM_AGE & -0.020 & 0.010 & -2.010 & 0.045 \\
\hline SIZE & 0.290 & 0.050 & 5.440 & 0.000 \\
\hline STATE & -0.020 & 0.080 & -0.250 & 0.750 \\
\hline TENUE & 0.080 & 0.020 & 3.460 & 0.000 \\
\hline
\end{tabular}

Notes: $* * *$ Significance level is $99 \%$ confidence, $* *$ Significance level is $95 \%$ confidence and * Significance level is $90 \%$ confidence.

Source: Research findings

According to the obtained results, the lagged dependent variable has a positive and significant effect on the agency costs; the effects of the audit committee, financial leverage, and firm age were negative and significant. Family firms and state firms have no significant impact on agency costs, while the firm size and CEO positively significantly affect the so-called factor.

The results of the Sargan test showed that the statistic of this test is equal to 11.36, and its probability level is 0.330 . So the test's null hypothesis is not rejected based on the statistic and probability level's value because the instrumental variables and the disruptive component are not correlated and have no validity. 
The results of the serial correlation test of model residuals are presented in the following table.

Table 7: serial correlation test of the third model residuals

\begin{tabular}{|l|c|c|}
\hline \multicolumn{1}{|c|}{ Autocorrelation order } & Statistic & Probability level \\
\hline First & 71 & 0.000 \\
\hline Second & 2.10 & 00.340 \\
\hline
\end{tabular}

Source: Research findings

According to the results, the disruptive components have the first-order autocorrelation. But no second-order autocorrelation was observed, so the instrumental variables are valid.

\section{Results and discussion}

Since the number of companies is more than years, the dynamic panel model and generalized method of moments were employed to enter the lagged dependent variable into the model. Results indicate that in all 3 models, the lagged dependent variable has a positive and significant impact, so ignoring the factors that create or surge the agency costs affects the current period's costs and magnifies the future costs. The audit committee's effect on the agency costs in all three models is high and negative, so establishing an audit committee lowers the agency costs. In other words, we can attribute such a significance to the positive role of the audit committee in fulfilling its duties, so we recommend the companies establish an audit committee to lower the agency costs. Also, recommend the capital supervision institutions pass some laws to pave the way for the development and decline of the agency costs and necessitate the establishment of audit committees. On the other hand, investors can use this result to select companies that have lower agency costs. Financial leverage's effectiveness on the agency costs is negative and significant, which implies that higher debt to assets ratio could reduce the agency costs. Being afraid of bankruptcy and paying the debts is one reason, and managers, to prevent such a risk adopted some contraction policies and diminished the agency costs. The effectiveness of family firms and state ownership on the agency costs is rejected in all three models in terms of statistical significance, so owners cannot prevent agency costs. The agency costs are formed based on the necessity and the state by using supervisory tools and even families. However, it is expected that trust, cooperation, and supervision supersede the agency costs to affect the agency costs' decline significantly. The impact of age on agency costs is considered negative and significant in all three models, so a higher lifetime causes fewer agency costs. The influence of CEO tenure on the agency 
costs is positive and significant in all three models, so results show that firms' longer management duration is not a positive issue and increases agency costs.

\section{Conclusions}

This study showed the importance of the impact of corporate governance components on agency costs. The results of all three models showed that among the four factors of corporate governance, the effect of agency cost interruption and CEO tenure on agency costs was positive and significant. In comparison, the audit committee's effect and financial leverage (as a control variable) on agency costs were negative and significant in all three models. There was also no relationship between family ownership and agency costs and state ownership and agency costs.

Researchers can add a dynamic element to the model in other aspects affecting agency costs and improve the fit by defining instrumental variables. On the other hand, the results pave the way for investors and capital market enthusiasts. In general, lower costs mean higher profits, so the results can help compare companies and choose the right portfolio. Given that all three models consider all three variables for agency costs, the results are the same. The coefficient and significance were obtained, considering that the amount of coefficients obtained is irrelevant in such studies. In addition to these results, the choice of indicators to represent the costs of representation is correct. On the other hand, researchers can use only one of them to do similar research.

Any attempt to reduce agency costs and reduce the current period will also reduce the agency costs in future periods (significant dependent variable interruption), requiring multiplicative accuracy in this area by managers. Financing through debt creation and leverage in companies is considered positive in terms of agency costs.

\section{References}

Alton. P. B. et al. (2007) "Improved global simulations of gross primary product based on a separate and explicit treatment of diffuse and direct sunlight", Journal of geophysical research, Vol. 112, No. 7, pp. 132-151, https://doi. org/10.1029/2006JD008022.

Anderson, R. C., Mansi, S. A., Reeb, D. M. (2003) "Founding family ownership and the agency cost of debt", Journal of financial economics, Vol. 68, No. 2, pp. 263-285, https://doi.org/10.1016/S0304-405X(03)00067-9.

Ang, J.S, Cole, R.A. and Lin, J.W. (2000) "Agency Costs and Ownership Structure", The Journal of Finance, Vol. 55, No. 1, pp. 81-106, https://doi. org/10.1111/0022-1082.00201. 
Antia, M., Pantzalis, C. Park. J.C. (2010) "CEO decision horizon and firm performance: an empirical investigation", Journal of corporate finance, Vol. 16, No. 3, pp. 288-301, http://dx.doi.org/10.2139/ssrn.1107422.

Arellano, M., Bond, S. (1991) "Some tests of specification for panel data: Monte Carlo evidence and an application to employment equations", Review of Economic Studies, Vol. 58, No. 2, pp. 277-297, https://doi.org/10.2307/2297968.

Arosa, B., Iturralde, T., Maseda, A. (2013) "The board structure and firm performance in SMEs: Evidence from Spain" Investigaciones Europeas de Direccion, Vol. 19, No. 3, pp. 127-135, https://doi.org/10.1016/j.iedee.2012.12.003.

Beshkooh, M. et al. (2015) "The relationship between audit quality and agency cost", Journal of Basic and Applied Scientific Research, Vol. 3, No. 2, pp. 516-525, https://www.textroad.com/pdf/JBASR/J.\%20Basic.\%20Appl. \%20Sci.\%20Res.,\%203(2)516-525,\%202013.pdf.

Brewer, B. and Featherstone, A.M. (2017), "Agency cost of debt: evidence from Kansas farm operations", Agricultural Finance Review, Vol. 77 No. 1, pp. 111124, https://doi.org/10.1108/AFR-03-2016-0023.

Buchwald, A. (2016) "Competition, outside directors and executive turnover: Implications for corporate governance in the EU", Managerial and Decision Economics, Vol. 37, No. 4-5, pp. 213-371, https://doi.org/10.1002/mde.2781.

Byrd, J. (2010) "Financial Policies and the Agency Costs of Free Cash Flow: Evidence from the Oil Industry", International Review of Accounting, Banking and Finance, Vol. 2, No. 2, pp. 23-50, https://doi.org/10.2139/ssrn.1664654.

Chiu, C. M., Hsu, M. H., Wang, E. T. G. (2006) "Understanding knowledge sharing in virtual communities: An integration of social capital and social cognitive theories", Decision Support Systems, Vol. 42, No. 3, pp. 1872-1888, https://doi. org/10.1016/j.dss.2006.04.001.

Chrisman, J. et al. (2007) "Are family managers agents or stewards? An exploratory study in privately held family firms", Journal of Business Research, Vol. 60, No. 3, pp. 1030-1038, https://doi.org/10.1016/j.jbusres.2006.12.011.

Chrisman, J. J., Chua, J. H., Reginald A. L. (2004) "Comparing the Agency Costs of Family and Non-Family Firms: Conceptual Issues and Exploratory Evidence", Entrepreneurship Theory \& Practice, Vol. 28, No. 5, pp. 335-354, https://doi.org/10.1111/j.1540-6520.2004.00049.x.

Dawar, V. (2014) "Agency theory, capital structure and firm performance: Some Indian evidence", Managerial Finance, Vol. 40, No. 12, pp. 1190-1206, https:// doi.org/10.1108/MF-10-2013-0275.

Dey, A. (2005) "Corporate Governance and Financial Reporting Credibility" Working Paper, Northwestern University, Kellogg School of Management, Evanston, Illinois, https://www.proquest.com/openview/9a2b15dbdb6f054822b $57 f 255 \mathrm{dc} 8 \mathrm{~b} 0 \mathrm{ce} / 1$ ?pq-origsite $=\mathrm{gscholar} \& \mathrm{cbl}=18750 \&$ diss $=\mathrm{y}$. 
Fama, E. F., Jensen, M. C. (1983) "Separation of Ownership and Control”, Journal of Law and Economics, Vol. 26, No. 2, pp. 301-325, https://www.jstor.org/ stable/725104.

Firth, M., Fang, P. M. Y., Rui, O. M. (2008) “Ownership, governance mechanisms and agency costs in chinas listed firms", Journal of asset management, Vol. 9, No, 2, pp. 90-101, https://doi.org/10.1057/jam.2008.13.

Fleming, G., Heaney, R., McCosker, R. (2005) "Agency Cost and Ownership Structure in Australia", Pacific Basin Finance Journal, Vol. 1, No, 13, pp. 29 52, https://doi.org/10.1016/j.pacfin.2004.04.001.

Florackis, C. (2008) "Agency costs and corporate governance mechanisms: evidence for UK firms", International Journal of Managerial Finance, Vol. 4, No. 1, pp. 37-59, https://doi.org/10.1108/17439130810837375.

Garanina, T., Kaikova, E. (2016), "Corporate governance mechanisms and agency costs: cross-country analysis", Corporate Governance, Vol. 16, No. 2, pp. 347360, https://doi.org/10.1108/CG-04-2015-0043.

Gonsales, B. et al. (2010) "Educational strategy on prevention of children's accidents for fundamental education", Public knowledge project, Vol. 6, No. 6, pp. 274-296.

Hong, B., Li, Z. H., Minor, D. (2015) "Corporate Governance and Executive Compensation for Corporate Social Responsibility", Springer Science+ Business, Vol. 136, No. 1, pp. 199-213, https://doi.org/10.1007/s10551-0152962-0.

Hunzikera, S. (2014) "Internal Control Disclosure and Agency Costs - Evidence from Swiss listed non-financial Companies", Technology and investment, Vol. 2, No. 4, pp. 286-294, https://doi.org/10.5281/zenodo.2577842.

Ilaboya, O. J., Obaretin O. (2015) "Board Characteristics and Firm Performance: Evidence from Nigerian Quoted Companies", Academic Journal of Interdisciplinary Studies, Vol. 4, No. 1, pp. 283-290, https://doi.org/10.5901/ mjss.2015.v4n1p283.

Jensen, M. C. (1986) "Agency Costs of Free Cash Flow, Corporate Finance, and Takeovers", American Economic Review, Vol. 76, No. 2, pp. 323-329, http:// dx.doi.org/10.2139/ssrn.99580.

Kilic, M. (2015) "The Effect of Board Diversity on the Performance of Banks: Evidence from Turkey", International Journal of Business and Management, Vol. 10, No. 9, pp. 182-192, https://doi.org/10.5539/ijbm.v10n9p182.

Kim, S., Pilotte, E., Yang, J. S. (2012) "Agency Costs and the Short-Run Stock Price Response to Capital Expenditures", The Financial Review, Vol. 47, No. 2, pp. 375-399, https://doi.org/10.1111/j.1540-6288.2012.00333.x.

Klein, A. (2002) "Economic determinants of audit committee independence", The Accounting Review, Vol. 77, No. 2, pp. 435-452, https://ssrn.com/abstract=291049. 
Li, H., Cui, L. (2003)“Empirical Study of Capital Structure on Agency Costs in Chinese Listed Firms", Nature and Science, Vol. 1, No. 1, https://www. semanticscholar.org/paper/Empirical-Study-of-Capital-Structure-on-Agency-inLi-Cui/2c6f495680cab9c05ab098e790bb642226be3c4c.

Li, H. X., Wang, Z. J., Deng, X. L. (2007) "Ownership, independent directors, agency costs a financial distress: evidence from Chinese listed companies", Corporate Governance: The international journal of business in society, Vol. 8, No. 5, pp. 622-636, https://doi.org/10.1108/14720700810913287.

Manos, R. et al. (2012) "Dividend policy and business groups: Evidence from Indian firms", International Review of Economics and Finance, Vol. 21, No. 1, pp. 42-56, https://doi.org/10.1016/j.iref.2011.05.002.

Moussa, F.B., Chichti, J. (2011) "Interactions between Free Cash Flow, Debt Policy and Structure of Governance: Three Stage Least Square Simultaneous Model Approach", Journal of Management Research, Vol. 3, pp. 1-34, https://doi. org/10.22495/cocv9i2art2.

Nazir S, Saita H.K. (2013) "Financial Leverage and Agency Cost: An Empirical Evidence of Pakistan", Int. Journal of Innovative and Applied Finance-IJIAF, Vol. 1, No. 1, https://www.semanticscholar.org/paper/The-Impact-of-FinancialLeverage-on-Agency-Cost-\%3A-Nazir-Nawaz/838991c8fb017bd2ad976ce3d4 bb6e135333cff4.

Obradovich, J., Gill, A. (2013) "The Impact of Corporate Governance and Financial Leverage on the Value of American Firms", Faculty Publications and Presentations, No. 91, https://digitalcommons.liberty.edu/busi_fac_pubs/25.

Rouf, M. A. (2011) "The relationship between corporate governance and value of the firm in developing countries", International Journal of Applied Economics and Finance, Vol. 5, No. 3, pp. 237-244, https://doi.org/10.3923/ijaef.2011. 237.244.

Russell, L.A., Briggeman, B.C., Featherstone, A.M. (2017) "Financial leverage and agency costs in agricultural cooperatives", Agricultural Finance Review, Vol. 77 No. 2, pp. 312-323, https://doi.org/10.1108/AFR-09-2016-0074.

Salehi, M., Sadatifar, Z., Adibian, M. (2020) "The Impact of the Characteristics and Behaviors of the Board of Directors on Agency Costs in Iran", Contaduría $y$ Administración, Vol. 66, No. 1, http://dx.doi.org/10.22201/fca.24488410e. 2021.2384.

Salehi, M., Salimi, S. (2017) "The effect of suspicious executives on tax shelters in Iran", Journal of Management Development, Vol. 36, No. 4, pp. 598-610, https://doi.org/10.1108/JMD-04-2016-0060.

Singh, M., Davidson, W. N. (2003) "Agency costs, ownership structure and corporate governance mechanisms", Journal of Banking \& Finance, Vol. 27, No. 5, pp. 793-816, https://doi.org/10.1016/S0378-4266(01)00260-6. 
Wang, D. (2006) "Founding family ownership and earnings quality", Journal of Accounting Research, Vol. 44, No. 3, pp. 619-656, http://dx.doi.org/10.1111/ j.1475-679X.2006.00213.x.

Yang, J. S., Krishnan, J. (2005) "Audit Committees and Quarterly Earnings Management”, Electronic copy available, Vol. 9, No. 3, pp. 201-219, https:// doi.org/10.1111/j.1099-1123.2005.00278.x.

YEO, H. (2012) "Impacts of the board of directors and ownership structure on consolidation strategies in shipping industry", The Asian Journal of Shipping and logistics, Vol. 28, No. 1, pp. 19-40, https://doi.org/10.1016/j.ajsl.2012. 04.002 .

Zhang, Y. (2010) "The effect of CEO tenure on CEO compensation: evidence from inside CEOs vs. outside CEO", Managerial finance, Vol. 36, No. 10, pp, 832859, https://doi.org/10.1108/03074351011070224. 


\title{
Odnos između karakteristika korporativnog upravljanja i agencijskih
} troškova

\author{
Mahdi Salehi ${ }^{1}$, Mohammad Sadegh Adibian ${ }^{2}$, Zakiyeh Sadatifar ${ }^{3}$, \\ Ehsan Khansalar ${ }^{4}$
}

\begin{abstract}
Sažetak
Cilj ove studije je procijeniti čimbenike koji doprinose agencijskim troškovima u Iranu. S tim u vezi, tijekom perioda 2010. - 2016. proučavano je 112 tvrtki. Budući da je model dinamičan i zavisna varijabla ima svojstvo zaostajanja, generalizirana metoda momenata koristi se za oslobađanje neovisnih varijabli $i$ ometajuće komponente. Nalazi ukazuju na značajno zaostajanje zavisne varijable u sva tri modela. Prisutnost odbora za reviziju značajno utječe na pad agencijskih troškova u sva tri modela. Štoviše, rezultati sugeriraju da obiteljska poduzeća i državni dioničari sva tri modela nemaju značajan utjecaj na agencijske troškove. Podudaranje financijske poluge prisutno je u sva tri modela što uzrokuje pad agencijskih troškova. Kad se promatra imovina, veće tvrtke temeljene na tri modela imaju i više agencijskih troškova.
\end{abstract}

Ključne riječi: agencijski troškovi, dinamički panel, generalizirana metoda momenata, faktorska analiza i odbor za reviziju

JEL klasifikacija: M41, C18

1 Izvanredni professor, Ferdowsi University of Mashhad, Postal code 9177948974, Mashhad, Iran. Znanstveni interes: revizija i financijsko izvješćivanje. Tel.:+989121425323. E-mail: mehdi.salehi@um.ac.ir. (Osoba za kontakt)

2 Doktorand, Ferdowsi University of Mashhad, Mashhad, Postal code 9177948974, Iran. Scientific affiliation: ekonometrijske metode i modeli, korporativne financije. Tel.: 989157001093. E-mail: Adib.mohammad@gmail.com.

3 Magistar ekonomskih znanosti, Imamreza International University of Mashhad, Postal code 916789412, Mashhad, Iran. Znanstveni interes: revizija i računovodstvo.E-mail: saadate94@ gmail.com.

4 Izvanredni profesor, Kingston University London, London, the UK. Znanstveni interes: financijsko izvješćivanje i računovodstvo. Tel.:+44 752 8593389, E-mail: e.khansalar@kingston.ac.uk. 